Boston University School of Law Scholarly Commons at Boston University School of Law

Faculty Scholarship

2010

\title{
The Education and Licensing of Attorneys and Advocates in South Africa
}

\author{
Peggy Maisel \\ Boston University School of Law
}

Follow this and additional works at: https://scholarship.law.bu.edu/faculty_scholarship

Part of the Law Commons

\section{Recommended Citation}

Peggy Maisel, The Education and Licensing of Attorneys and Advocates in South Africa, 79 The Bar Examiner 2 (2010).

Available at: https://scholarship.law.bu.edu/faculty_scholarship/572

This Article is brought to you for free and open access by Scholarly Commons at Boston University School of Law. It has been accepted for inclusion in Faculty Scholarship by an authorized administrator of Scholarly Commons at Boston University School of Law. For more information, please contact lawlessa@bu.edu. 


\title{
Law
}

\section{The Education and Licensing of Attorneys and Advocates in South Africa}

\author{
By Peggy Maisel
}

\section{FIU Legal Studies Research Paper Series}

\author{
Research Paper No.10-33
}

October 2010

This paper can be downloaded without charge from the Social Science Research Network electronic library at:

$\underline{\text { http://ssrn.com/abstract }=1695704}$ 


\title{
THE EDUCATION AND LICENSING OF ATTORNEYS AND ADVOCATES IN SOUTH AFRICA
}

\author{
by Peggy Maisel
}

$\mathrm{T}$ his article explores the current organization of the South African bar and describes the legal education system and the licensing requirements for both attorneys and advocates, as well as those for foreign attorneys. Interspersed throughout the article are discussions of the system's strengths and weaknesses, particularly in light of the transformation required after the end of apartheid, including some of the key challenges still facing South Africa.

\section{The Legal System OF SOUTH AfricA}

South Africa's legal system has always been complex because its foundation includes elements of English common law, Roman-Dutch law, and indigenous African law. ${ }^{1}$ Like England, it also has a divided bar of attorneys and advocates, ${ }^{2}$ the latter doing all but the most simple work in court and therefore traditionally becoming judges. ${ }^{3}$ Under apartheid, the legal profession, like all other institutions, was segregated, which meant there were separate law schools for whites and nonwhites, and courthouses had separate entrances, halls, rooms, and counsel tables for black and white members of the profession and the public. Not surprisingly, the bar included very few members of color despite the fact that South Africa's population is about 79\% black African, 9\% colored, 3\% Indian, and 9\% white. ${ }^{4}$

Formal apartheid ended in 1994 when Nelson Mandela, who was a lawyer, was elected president in the country's first truly democratic elections. A permanent constitution was then enacted in 1996 to replace the interim one that had been negotiated between the government and the African National Congress and its allies. Parallel changes to the legal profession included the integration of university law faculties, the updating of curriculum, ${ }^{5}$ and the amendment of the Legal Practice Act regarding admission to the bar. ${ }^{6}$

For example, the requirement that applicants for admission as advocates and attorneys pass examinations in English and Afrikaans was abolished, ${ }^{7}$ and a Legum Baccalaureus (LL.B.) was made the universal educational requirement for admission to either branch of the legal profession. ${ }^{8}$ In addition, legal practice schools were started in 1994 to increase preparation for and access to the legal profession, ${ }^{9}$ a community service option was instituted as an alternative to the two-year apprenticeship requirement that excluded many black law graduates from entering the profession, ${ }^{10}$ the professional bodies that regulate the bar examination and admission were integrated, and many formerly segregated legal organizations were merged. ${ }^{11}$ An additional reform currently being debated in Parliament would do away with the divided bar. ${ }^{12}$ As a result of these changes, the diversity of the profession has significantly increased; however, much remains to be done, and legal educators, attorneys, and advocates must continue to play key roles in this transformation process. 


\section{Legal EdUCATION IN SOUTH Africa}

Legal education in South Africa has two distinct phases functioning in tandem to prepare candidates for admission to legal practice. The first, described in this section, consists of a four-year LL.B. degree conferred by one of the 18 university law faculties. This has been the system since 1998, when South African law schools began to offer the same degree for those planning to be either attorneys or advocates. ${ }^{13}$ The second, described in the following two sections, consists of some form of post-lawschool apprenticeship, coursework, and a bar examination designed to prepare candidates and assess their qualifications for admission as either attorneys or advocates.

\section{The LL.B. Curriculum}

When the four-year LL.B. degree was adopted in 1998, the law school deans agreed that each school would design a curriculum based on 26 core courses that would include the teaching of legal skills, values, and sensitivity to diversity in addition to substantive law. In 2002 the four-year undergraduate LL.B. degree was registered by the South African Qualification Authority, the national accreditation authority for all university education, and exit-level outcomes for law graduates were specified..$^{14}$

The core curriculum includes all the courses taught in the first year at a U.S. law school. In addition, there are basic courses which are considered electives in the United States ${ }^{15}$ plus, at most law schools, practical skills training, a moot court requirement that is normally part of a legal practice course, and a clinical law experience. Indeed, all South African law schools have live client clinics. ${ }^{16}$ Therefore, even students who decide not to practice law have the opportunity or requirement (whether the course is optional or required depends on the law school) to learn some basics of legal practice before graduating from law school. At the University of KwaZulu-Natal, for instance, a clinical experience is required for all final-year students, who can choose between representing clients and taking a course at the Campus Law Clinic, teaching high school students as part of the Street Law program, or completing a course that teaches them how to teach legal skills to first-year students.

\section{Problem Areas in Legal Education}

The historic inequalities in students' educational backgrounds caused by apartheid constitute by far the biggest problem in legal education. This is not surprising since educational statistics from the last 13 years of that era "reflect gross inequalities in per capita spending, pupil-teacher ratios, teacher pay scales, school facilities, compulsory education requirements, school attendance practices, secondary school matriculation rates, and university entrance examinations." ${ }^{17}$ As a result of deficiencies in writing and basic numeracy skills, more law students from disadvantaged educational backgrounds experience difficulties during law school and on the bar examination and ultimately are unprepared for legal practice. 
Two factors inhibiting remediation of this problem are that at most law schools classes other than the clinical and skills classes mentioned earlier are taught in English or Afrikaans, and they are taught in a large lecture format. ${ }^{18}$ The language issue contributes to the poor pass rates because students are being taught in their second or third language, while the lecture format makes it difficult to use the pedagogy necessary to address individual problems, such as writing deficits.

In response to this ongoing problem, the South African Law Deans' Association has commissioned an empirical study to both appraise the state of legal education in South Africa and suggest solutions. ${ }^{19}$ Even before its completion, legal educators have begun developing curricula and pedagogies in an attempt to improve poor student pass rates. For example, several law schools have replaced the survey course taught in a large lecture format that formerly comprised the first-year law curriculum with a skills-oriented class, taught primarily in small sections, that emphasizes the development of writing, numeracy, and computer skills.

Despite these changes, law schools will still need to do more to remediate the deficiencies of primary and secondary education for many students. Findings of the empirical study currently under way will hopefully lay out a blueprint for change; but success can only be accomplished if there is a significant increase in resources to law schools from the government or from donors and if those resources are used creatively and effectively.

\section{THE LiCENSING OF AdVOCATES AND THE NATIONAL BAR EXAMINATION}

\section{What Advocates Do}

In South Africa's divided bar, advocates handle most litigation, even though they constitute only about
$13 \%$ of practicing lawyers. Only advocates can appear before the country's Supreme and Constitutional Courts. Their work focuses on research, drafting opinions and pleadings, and presenting cases in court. An advocate cannot solicit a case directly from a client. It is the attorney, not the client, who approaches the advocate and who instructs the advocate regarding the case.

No specialties exist for advocates in South Africa. However, after at least 10 years of practice, advocates of proven experience and skill may be appointed as senior consultus, also known as silks because of the traditional silk robes they wear. Regional bar associations make recommendations as to who should be appointed as silks to the president of South Africa, who makes the appointments. Silks are therefore considered the leaders of the profession, ${ }^{20}$ and judges traditionally are chosen from their ranks. ${ }^{21}$

\section{Admission Requirements}

To become an advocate, a candidate must meet the following requirements:

1. be over 21 years of age and a "fit and proper person,"

2. be "duly qualified" (defined as having completed an LL.B. degree), ${ }^{23}$

3. be either a South African citizen or a permanent resident, and

4. apply to be removed from the roll of attorneys if the applicant has been admitted as an attorney in any jurisdiction. ${ }^{24}$

The process to become an advocate involves three steps: obtaining an LL.B. degree, completing one year of pupilage, and passing the National Bar Examination. ${ }^{25}$ Even though there is no statutory requirement to become a member of a bar association, 
the traditional and most recognized route to becoming an advocate requires admission to one. This is so because the General Council of the Bar (GCB), a national body, and the 12 regional bar associations ${ }^{26}$ regulate and represent advocates and administer admission to the profession. ${ }^{27}$

As an alternative, the Association of Independent Advocates of South Africa was formed in 1994 to represent advocates who do not become members of the "traditional" bar. ${ }^{28}$ Despite their independence, these advocates are still subject to discipline by the High Court, which has supervisory jurisdiction over all legal professionals based on complaints filed by either the GCB or the regional bar associations. ${ }^{29}$ The latter do not have the power to suspend or remove advocates from the roll of advocates, but the admitting bar association can make an application to a court, which has the power to do so. ${ }^{30}$

Application for pupilage generally takes place prior to completion of the LL.B. and includes application for admission as an advocate. ${ }^{33}$ Pupilage generally begins on January 15 and runs through the end of December. Pupils perform both general work and specifically prescribed work under the supervision of their mentors, ${ }^{34}$ and all of the pupils' work is reviewed. In addition, pupils attend a lecture series, ${ }^{35}$ participate in advocacy training exercises, and perform written exercises. ${ }^{36}$ Each

EACH PUPIL IS REQUIRED TO MAINTAIN A DIARY OF ALL ACTIVITIES AND WORK PERFORMED, WHETHER IT WAS PERFORMED WITH A MENTOR OR WITH OTHER MEMBERS OF THE BAR, AND HE OR SHE IS ENCOURAGED TO MAINTAIN A FILE CONTAINING SAMPLES OF DOCUMENTS THAT THE PUPIL WILL USE LATER IN PRACTICE.

PUPILS ARE ALSO ENTITLED TO AND ENCOURAGED TO APPEAR IN COURT AND MUST COMPLETE A COURSE OF PRACTICAL EXERCISES BASED ON A WORKBOOK MANUAL. pupil is required to maintain a diary of all activities and work performed, whether it was performed with a mentor or with other members of the bar, and he or she is encouraged to maintain a file containing samples of documents that the pupil will use later in practice. ${ }^{37}$ Pupils are also entitled to and encouraged to appear in court and must complete a course of practical exercises based on a workbook manual. $^{38}$

During the month of July,

\section{Professional Training}

The training to become an advocate, including a one-year pupilage, is provided by the regional bar associations. ${ }^{31}$ During this time, pupils are closely monitored by mentors, who must have at least five years of experience as advocates, and supervisors, who come from the ranks of silks. The supervisors are required to meet with pupils on a bimonthly basis and are charged with ensuring that pupils are properly mentored and that they fulfill all pupilage requirements. ${ }^{32}$ pupils prepare themselves for the National Bar Examination, which is administered in August. If the pupil passes the examination, he or she must complete an Advocacy Training Course in November, and the month of December is used for further mentoring and preparation for practice. Once a pupil has passed the National Bar Examination, the pupil is permitted to appear independently in court and accept briefs from attorneys, provided that the pupil is supervised by the mentor and discloses to the attorney, the judge, and the court his or her status as a pupil. 
Failure of the bar examination is considered failure of pupilage. Therefore, if a pupil fails the bar examination, he or she must repeat the entire year of pupilage. Pupils are limited to two periods of pupilage, with a third permitted if special circumstances exist. $^{39}$

\section{The National Bar Examination}

The National Bar Examination, which is held in August of each year, consists of six parts: Legal Writing, which is an open-book exam, and Motion Court, Ethics, Criminal Procedure, Civil Procedure for the High Court, and Civil Procedure for the Magistrate's Court, which are all closed-book exams. ${ }^{40}$ The written exams are graded internally and then moderated by a panel of three judges. Based on the results, some applicants may be required to take oral examinations in September in order to give those students who did not do well on the written examination the opportunity to show that they should pass the bar examination. ${ }^{41}$ The time between the written and oral portions of the examination is used for remedial teaching. ${ }^{42}$

If a pupil fails the bar examination but has passed any subject with a grade of $65 \%$ or better, he or she is exempted from retaking that portion of the exam. However, he or she will still have to repeat the oneyear pupilage since, as noted earlier, failing the bar examination results in failing pupilage. ${ }^{43}$ The overall bar exam pass rate in 2007 increased to $89 \%,{ }^{44}$ with some regional bars actually obtaining a $100 \%$ pass rate. ${ }^{45}$ However, the main reason for failing pupilage continues to be failure of the bar examination.

\section{Problems with the Advocate Licensing System}

Although there has been much praise for the workbook portion of the pupilage course, the lecture series has been the subject of criticism from both pupils and those involved in their training. ${ }^{46}$ Among the complaints are that the lectures do not focus on the syllabus and that the participants are unable to ask questions of the lecturer. In response, an experiment is currently under way to replace lecturers with "facilitators" who teach small groups of pupils using practical exercises. Interaction with both the facilitators and other pupils is encouraged, and feedback is provided on each pupil's performance. ${ }^{47}$

There are also many criticisms of the bar examination. Chief among these is that, except for the legal writing section, it tests academic knowledge and pupils' ability to memorize large volumes of rules and principles rather than their ability to perform as advocates. ${ }^{48}$ One consequence of this type of testing is that many candidates who are highly rated by their respective regional bars and who are competent to begin practice fail the exam, often by just a few points. ${ }^{49}$

In addition, since failure in just one subject area of the bar exam can mean complete failure of pupilage, and since pupils are given no credit for the practical work they perform under their mentors' supervision or for the training they receive, ${ }^{50}$ an examination-only testing system is not seen as a complete or fair way to judge competence. Indeed, critics argue that it may exclude some candidates who are fit to be advocates and admit some who are not. ${ }^{51}$ Even more consequential is the fact that since few pupils have the resources or stamina to repeat the entire year of pupilage, this failure effectively bars them from the more recognized means of admission to the profession.

Two key contributors to the system ${ }^{52}$ have suggested a number of changes to the National Bar Examination and the system of pupilage, including 
- giving supplementary examinations in individual subjects for pupils who fail one or more of the subjects,

- viewing the examination not as a requirement for entry to the profession but as a way to identify pupils who need further training before being admitted to practice, ${ }^{53}$

- weighting each portion of the examination so that failure in a single subject does not necessarily result in complete failure of the exam, and

- assigning credits to each portion of pupilage, to be considered along with the bar exam score in determining competency. ${ }^{54}$

Others have suggested even more extensive changes such as

- making the entire bar examination an openbook exam; ${ }^{.5}$

- standardizing pass scores (for example, a firm $50 \%$ pass score);

- enhancing supervision and monitoring of pupils and establishing record keeping so that those pupils who need extra assistance can be detected and so that mentors can be made more accountable; ${ }^{56}$ and

- providing extra attention to pupils coming from high-risk categories (such as pupils with no prior legal experience either as attorneys, legal advisors, or public prosecutors, pupils whose first language is not English, and pupils who attended a former homeland university). ${ }^{57}$

Despite the fact that there have been major changes in the professional training of advocates and in the bar examination since the end of apartheid, further improvements clearly are needed in order to open the profession to all law graduates. South Africa is fortunate to have competent experts available to help redesign the system. What is needed now is support and resources from bar and government leaders to implement the needed changes.

\section{The LiCENSING OF ATtORNEYS AND THE ATTORNEYS' ADMISSION EXAMINATION}

\section{What Attorneys Do}

Eighty-seven percent of law graduates who are licensed in South Africa become attorneys rather than advocates. ${ }^{58}$ Their practice consists of consulting with clients directly and performing the bulk of everyday legal work ${ }^{59}$ such as drafting legal documents, negotiating settlements, preparing cases for presentation in court, ${ }^{60}$ and conducting trials in the lower courts and upon application in the High Court. ${ }^{61}$ When necessary, they brief advocates for litigation. They are usually general practitioners, working in firms or sometimes independently. With advanced study, attorneys may qualify for two specialized licenses: the Notary Public and the Conveyancer, or property attorney. These require the successful completion of examinations regarding the law, practice, functions, duties, and procedures associated with the specialty. ${ }^{62}$

\section{Admission Requirements}

Requirements for admission as an attorney include

1. being a citizen or permanent resident of South Africa, at least 21 years of age, and a "fit and proper person"; 63

2. obtaining an LL.B. from or recognized by a South African university; ${ }^{64}$

3. completing either (a) articles of clerkship (a form of apprenticeship) for two years, (b) a four-month practical training course and one 
year of community service ${ }^{65}$ or articles, or (c) two years of community service;

4. completing a five-week legal training course ${ }^{66}$ and

5. passing the Attorneys' Admission Examination administered by the relevant regional law society.

To be permitted to practice, an attorney must also possess a Fidelity Fund Certificate, issued by his or her corresponding regional law society, the purpose of which is to insure against misuse of client trust funds. ${ }^{67}$

The Law Society of South Africa (LSSA) is the national representative umbrella body for attorneys, ${ }^{68}$ but regional law societies are the bodies that license, regulate, and discipline attorneys. ${ }^{69}$ To carry out these functions, the four regional law societies are empowered to investigate cases of unprofessional, dishonorable, or unworthy conduct on the part of any attorney, notary public, conveyancer, person serving articles or clerkship, or former candidate attorney.$^{70}$ If a law society finds an attorney guilty of misconduct, it can fine, reprimand, or either temporarily or permanently suspend the attorney. ${ }^{71}$

\section{Professional Training}

\section{Articles of Clerkship}

Until 1994, one of the requirements for admission as an attorney was to complete articles of clerkship. As explained later in this section, alternative paths have since been implemented that allow candidates to either reduce or eliminate this requirement.

To complete articles, the candidate attorney, or graduate, finds a practicing attorney with at least three years of experience to act as a principal, or supervisor, to prepare the candidate for the practice of law. The candidate attorney and the principal sign a contract that contains an exchange of promises, including a pledge by the candidate attorney to use diligence, honesty, and confidentiality, while the principal agrees to provide proper instruction in the areas of legal practice, ethics, and understanding. The candidate attorney is required to keep a diary of the training he or she receives that must be available to both the principal and the law society in the province where he or she is located. The law society at least nominally oversees the process and is the authority that ultimately certifies the candidate attorney. Finally, the principal agrees to use his or her best efforts to assist the candidate attorney in gaining admission, assuming successful completion of the

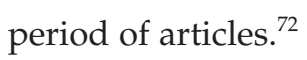

Since it is the candidate attorney's responsibility to find the law firm or lawyer for articles, the practical effect of this requirement has been to make it more difficult for nonwhite law graduates to obtain admission as attorneys. Consequently, reforms were instituted in 1994 to provide alternatives to 
articles that allow for greater access to the profession. Law graduates can now fulfill the two-year articles requirement through either a four-month practical training course and one year of articles or community service, or two years of community service. ${ }^{73}$ Community service is defined as full-time service related to the application of the law at a legal clinic or an office of the Legal Aid Board. ${ }^{74}$

\section{Practical Training Course}

The practical training course that qualifies the candidate attorney for a reduction of time in serving articles was developed by the Legal Education and Development Division (L.E.A.D.) of the LSSA. (It actually runs for five months, although the statute only requires four. ${ }^{75}$ ) An added bonus for those who take the course is that they are exempted from taking the five-week legal training course, which is otherwise one of the requirements for admission. ${ }^{76}$

The five-month course consists of four modules that focus on practical skills required during practice. ${ }^{77}$ The pedagogy is designed to be more clinical, and instructors use simulations and other teaching methodologies designed to prepare lawyers for practice. Students are divided into "firms" that work together to complete assigned tasks in competition with other similarly constituted firms in mock litigation. Assessments are provided at the end of each module, with emphasis placed on the learning of skills.

The instructors are often either members of university law faculties who have practical legal experience, or full-time practicing attorneys. They are paid at a higher rate than are teachers of university courses, so such instructorships are prized positions. According to graduates, the quality of the courses varies depending on how grounded the faculty members are in clinical teaching methodology and how much time they have to devote to students. ${ }^{78}$

\section{Legal Training Course}

The third statutory admission requirement for all candidate attorneys, except for those who have completed the five-month practical training course, is a five-week legal training course. ${ }^{79}$ The course consists of two modules and is practice oriented, designed to supplement the training received during articles or community service regarding the knowledge, skills, and attitude of a competent attorney and to prepare candidates for the Attorneys' Admission Examination (although the course is not required prior to sitting for the Attorneys' Admission Examination). ${ }^{80}$ L.E.A.D. has developed a training course that satisfies the statutory requirement, and it, rather than the regional law societies, administers the course. ${ }^{81}$ The course is offered at 12 different centers located throughout South Africa, 11 of which are attached to universities.

\section{The Attorneys' Admission Examination}

The fourth requirement, the Attorneys' Admission Examination, though administered by the four regional law societies, is prepared by the Examinations Committee of the LSSA and is therefore a national examination. ${ }^{82}$ To sit for the Attorneys' Admission Examination, a candidate must have completed at least six months of articles, the community service requirement, or the four-month ${ }^{83}$ practical training course. $^{84}$

The exam consists of four sections called papers and is offered twice a year over a period of two days. Unlike those taking bar exams in the United States, candidates do not have to complete all portions of the exam in a designated order during a single exam period; they have the option of completing the four 
papers in any sequence. ${ }^{85}$ If a candidate fails any of the four papers, he or she may take that paper again at another sitting.

The Attorneys' Admission Examination is a practical test of candidates' ability to draft legal documents, pleadings, motions, and affidavits as well as their knowledge of legal procedure and ethics. ${ }^{86}$ Compared to the bar exam in the United States, the Attorneys' Admission Examination can perhaps be viewed as a hybrid between the exam given to law school graduates and the Attorneys' Examination given in some U.S. jurisdictions to attorneys who have already been admitted in a different jurisdiction.

The four papers cover practice and procedure in the High and Magistrates' Courts; criminal procedure and motor vehicle accidents; the practice, function, and duties of an attorney, including administration

THE EXAM CONSISTS OF FOUR SECTIONS CALLED PAPERS AND IS OFFERED TWICE A YEAR OVER A PERIOD OF TWO DAYS. UNLIKE THOSE TAKING BAR EXAMS IN THE UNITED STATES, CANDIDATES DO NOT HAVE TO COMPLETE ALL PORTIONS OF THE EXAM IN A DESIGNATED ORDER DURING A SINGLE EXAM PERIOD; THEY HAVE THE OPTION OF COMPLETING THE FOUR PAPERS IN ANY SEQUENCE. some LL.B. graduates demonstrate a "shocking" lack of numeracy, writing, research, and computer skills. ${ }^{89}$

L.E.A.D. has informed the law school deans that they must introduce coursework in the LL.B. program that addresses these deficiencies, and has introduced business writing and numeracy courses in the coursework of the legal practice schools. In addition, L.E.A.D. has recently announced a skills development initiative for practicing attorneys and LL.B. graduates. $^{90}$

At the professional training level, the problem with the traditional system of articles, as described previously, is the difficulty experienced by nonwhite candidate attorneys in obtaining principals to supervise them. ${ }^{91}$ The suggestion has been made that, because articles are generally required for admission, a state institution should administer them to ensure that there are enough positions for all candidates seeking admission. ${ }^{92}$ In response, the Law Society argues that the problem has been addressed by the ability to reduce the length of articles or substitute other forms of training, ${ }^{93}$ but the fact remains that only white candidates have the full array of alternatives available to fulfill this requirement.

Also, many candidates completing articles complain that their principals do not provide them with the required training, such as supervision in court, or, even worse, that they are never even sent to court. ${ }^{94}$ Some even claim disrespectful treatment by their principals. ${ }^{95}$ One remedy suggested is that 
the Law Society monitor the principals, ${ }^{96}$ but it has argued that this is not cost-effective and that requiring more of practitioners who serve as principals will reduce the availability of articling positions. ${ }^{97}$ In addition, the Law Society argues that the required five-week legal training course for most candidate attorneys (not required for those who follow the alternate path to articles by taking the practical training course) addresses any deficiencies in practical training encountered during articles.

Critics complain that the five-week legal training course suffers from the same deficiencies as the five-month practical training course. The latter, which has proved not to be a solution to the problem of inadequate training during articles, is seen as using teaching methodologies that concentrate too much on substantive law over practice skills even though its pedagogy is supposed to be practice oriented. ${ }^{98}$ Additionally, some students, especially those with the least amount of practical experience, argue that they gain little insight into legal practice because the competitive nature of the course ${ }^{99}$ creates a situation in which those who have more experience end up performing most of the work, providing little practice to those who need it most. ${ }^{100}$ In fact, the director of Practical Legal Training at the LSSA states that $90 \%$ of those taking the course still feel a need for real-life practical training. ${ }^{101}$

Finally, critics of the Attorneys' Admission Examination question its relevance, arguing as in other countries such as the United States that the exam does not achieve the purpose of testing the ability to practice as an attorney but rather tests the ability to memorize substantive law and procedure. ${ }^{102}$

\section{The Licensing ANd PRACTICE OF FOREIGN ATTORNEYS}

Because South Africa has one of the most important economies on the continent, a number of international law firms and companies have offices in South Africa. Current rules allow foreign firms to open offices there under home title (the title granted by the attorney's home jurisdiction). In that capacity, lawyers working for those firms are permitted to practice home and international law as well as international finance, project management, and arbitration. ${ }^{103}$ Attorneys licensed outside of South Africa are not, however, permitted to appear in court or practice in conjunction with or enter into fee-sharing arrangements with South African firms. They are considered to be practicing foreign law and are therefore considered to be legal consultants and not attorneys or advocates; they are also not subject to discipline by the law societies. ${ }^{104}$

In order for foreign lawyers to be permitted to practice in South African courts, they must have completed the same process as South African attorneys. ${ }^{105}$ They also must have either South African citizenship or permanent residency and satisfy the court that they are "fit and proper persons."106 Limited concessions have been made to ease the process, primarily for South Africa's neighbors. For example, the education requirement can be satisfied if a South African university's law faculty certifies that the degree held by the applicant has a syllabus of instruction and a standard of training that is equivalent or superior to those of the South African LL.B. degree. ${ }^{107}$ Additionally, a degree already designated as certified from a limited number of specified countries is sufficient. ${ }^{108}$ (Currently, only degrees from Swaziland, Zimbabwe, and TBVC statesformer homeland states during apartheid—have that 
designation.) ${ }^{109}$ Finally, some foreign attorneys (currently those from Zimbabwe and Namibia) are exempted from some admission requirements such as articling and examination, ${ }^{110}$ while full crossborder practicing rights are only currently available to attorneys from Lesotho. ${ }^{111}$

\section{Challenges fOR the Future}

A controversial question currently being debated in many countries is whether to require a bar examination. South African legal education follows that of other Commonwealth countries with requirements for an LL.B. degree followed by postgraduate apprenticeship and practical training. But on the question of whether to require passage of a bar examination, the Commonwealth countries differ. Thus, Australia has no bar examination. ${ }^{112}$ In Scotland, those who wish to be advocates must have passed a bar examination prior to pupilage, ${ }^{.13}$ solicitors, on the other hand, need only complete a practical training course and two years of training after the LL.B. ${ }^{114}$ Similarly, solicitors in England and Wales do not have to take an examination, ${ }^{115}$ while starting this year, prospective barristers must pass three examinations in Civil Litigation, Criminal Litigation, and Ethics. ${ }^{116}$

Despite other reforms, South Africa continues to require passage of a bar examination for both attorneys and advocates. Very little change has occurred even though the exams have been severely criticized, especially because they disproportionately exclude nonwhite candidates from the profession and are seen as too academically oriented.

Another trend in other Commonwealth countries has been to merge the advocate and attorney professions into a unified bar as exists in the United States. This change is well under way in the European Union. ${ }^{117}$ Such a merger has been proposed in South Africa and there has been some movement in that direction with the recent expansion of attorneys' roles to allow practice in the High Courts.

These trends and others reflect the changes in the legal profession brought about by the globalization of legal practice. The added challenge for South Africa has been and remains how to reshape the legal profession, including the judiciary, so that it is more reflective of the country's population. Significant improvements have already been made in this regard, as described earlier. Nevertheless, if apartheid's effect on the legal system is to be eliminated, much more needs to be done to improve both opportunities for and the quality of legal education and practical skills training for people of color. Achieving this goal will require further changes to the statutory framework and regulations of governing organizations as well as to law school curricula and postgraduate training.

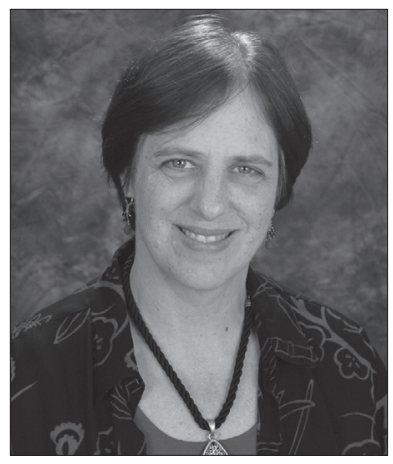

Margaret (Peggy) Maisel, Associate Professor and Founding Director of the Clinical Program at Florida International University College of Law, was a Fulbright Professor in 1996 at the University of KwaZulu-Natal in Durban, South Africa, where she was later hired as an Associate Professor from 1997 to 2002. With a colleague, Lesley Greenbaum, she published two textbooks that revamped the curriculum for first-year students, Introduction to Law and Legal Skills and Foundations of South African Law, and she has written and spoken widely on South African legal education and access to justice.

\section{Notes}

1. Supreme Court of Appeal of South Africa, History and Background, http://www.justice.gov.za/sca/historysca.htm (last visited Feb. 8, 2010).

2. Advocates are known as barristers in England, while attorneys are called solicitors. Julian Lonbay, The Education, 
Licensing, and Training of Lawyers in the European Union, Part I: Cross-Border Practice in Member States, 77 THe BAR ExAMINER 4:6, at 7 (Nov. 2008).

3. General Council of the Bar of South Africa, South African LegalSystem,http://www.sabar.co.za/legal-system.html(last visited Jan. 6, 2010).

4. Statistics South Africa, Mid-Year Population Estimates 2009, available at http://www.statssa.gov.za/publications/P0302/ P03022009.pdf. These racial classifications were formalized in the Population Registration Act 30 of 1950, amended in 1959. The term black was and is still used to include Africans, persons of mixed race, and persons of Indian (or Asian) origin. The term coloured was used for people of mixed-race origins.

5. See Peggy Maisel, Expanding and Sustaining Clinical Legal Education in Developing Countries: What We Can Learn from South Africa, 30 Fordham Int'L L.J. 374, at 374 n.3 (2007).

6. See Attorneys Act 53 of 1979 [hereinafter Attorneys Act], available at http://www.justice.gov.za/legislation/acts/1979 -053.pdf, and Admission of Advocates Act 74 of 1964, available at http://www.doj.gov.za/legislation/acts/1964-074.pdf, both amended by Admission of Legal Practitioners Amendment Act 33 of 1995, available at http://www.justice.gov.za/ legislation/acts/1995-033.pdf, and Qualification of Legal Practitioners Amendment Act 78 of 1997, available at http:// www.info.gov.za/view/DownloadFileAction?id=86707.

7. Admission of Legal Practitioners Amendment Act 33 of 1995, available at http://www.justice.gov.za/legislation/acts/ 1995-033.pdf.

8. Qualification of Legal Practitioners Amendment Act 78 of 1997, available at http://www.info.gov.za/view/DownloadFile Action?id=86707. Prior to this, a five-year LL.B. degree was required for admission as an advocate, while attorneys were required to obtain a four-year Baccalaureus Procurationis (B.Proc.) degree recognized by the Board for the Recognition of Examinations in Law.

9. This was instituted through the Attorneys Amendment Act 115 of 1993, available at http://www.info.gov.za/view/ DownloadFileAction?id=89907.

10. See Attorneys Act, supra note 6, at $\S \S 2(1 \mathrm{~A}), 2 \mathrm{~A}$.

11. See The Law Society of South Africa, History, http://www.lssa .org.za/Index.cfm?fuseaction=home.page\&PageID=9593558 (last visited Jan. 7, 2010).

12. See Legal Practice Bill, First Working Draft, 2009, available at http://www.lssa.org.za/Uploads/files/Legal\%20practice\%20 Bill\%202009\%20working\%20draft\%201A\%20\%20August \%202009\%20_2_(1).pdf.

13. Qualification of Legal Practitioners Amendment Act 78 of 1997, supra note 8, at $\S \S 1-2$.
14. Lesley Greenbaum, A History of the Racial Disparities in Legal Education in South Africa, 3 John Marshall L.J. 1:1, at 11 (Summer 2009).

15. As in U.S. law schools, South African law schools require that students take Constitutional Law, Contracts, Delict (equivalent to our system of Torts), Civil Procedure, Criminal Procedure, Criminal Law, Evidence, and Property. Additionally, Administrative Law, Succession, International Law, Interpretation of Statutes, and Corporations, or other forms of business-related law, are required at all law schools. Most, but not all, also require African Customary Law, Family Law, and Labor Law. See University of South Africa, Degree of Bachelor of Laws, available at http://brochure.unisa .ac.za/brochure/data/pdf/03492.pdf; Stellenbosch University Faculty of Law, 2010 Calendar, pp. 14-16 and 278-36, available at http://www.sun.ac.za/university/jaarboek/2010/ Regsgeleerdheid2010Eng.pdf; KwaZulu-Natal Faculty of Law, Handbook for 2010, pp. 35-38, available at http:// law.ukzn.ac.za/Libraries/Policies/Fac85Handbook2010.sflb .ashx; University of Cape Town, Faculty of Law, 2010 Handbook, pp. 6-9, available at http://www.uct.ac.za/downloads/ uct.ac.za/apply/handbooks/fac_law_2010.pdf.

16. Maisel, supra note 5, at 374 n.2.

17. Alfreda A. Sellers Diamond, Constitutional Comparisons and Converging Histories: Historical Developments in Equal Educational Opportunity Under the Fourteenth Amendment of the United States Constitution and the New South African Constitution, 26 Hastings Const. L.Q. 853, 874-875 (1999). It was believed by the apartheid government that " $[\mathrm{t}]$ here is no place for [the African] in the European community above the level of certain forms of labour. It is of no avail for him to receive a training which has as its aim, absorption in the European community." Consequently, the education for nonwhites was limited in order to maintain blacks as laborers and servants. SouthAfrica.info, Education in South Africa, citing H.F. Verwoerd, the architect of the Bantu Education Act of 1953, http://www.southafrica.info/about/ education/education.htm; last visited Feb. 26, 2010.

18. At Stellenbosch University the primary language of instruction at the undergraduate LL.B. level is Afrikaans, while graduate courses are taught in English. Faculty of Law Yearbook 2010, at 2, available at http://www.sun.ac.za/ university/jaarboek. The University of the Free State teaches in a "parallel system" where all courses are offered in both English and Afrikaans. Language Policy of the University of the Free State $\S 3.1$, available at http://www.ufs.ac.za/ documents/ufs_facts/taal/E_Language\%20Policy.pdf.

19. Greenbaum, supra note 14 , at 17.

20. General Council of the Bar of South Africa, Do You Want to Be an Advocate?, http://www.sabar.co.za/legal-career.html (last visited Jan. 8, 2010). 
21. Sharon Meadows, Implementing the Right to Counsel in PostApartheid South Africa, 29 Geo. WAsh. J. InT'L L. \& Econ. 453, at 475 (1995).

22. To prove that he or she is fit and proper to be admitted, an applicant must provide a testimonial from the dean of the law school, two personal references, and any information, including criminal charges, that may reflect on the candidate's fitness. KwaZulu-Natal Bar, Pupillage, Application for Membership, available at http://www.kznbar.co.za/pupillage .asp (last visited Feb. 6, 2010).

23. Admission of Advocates Act 74 of 1964, supra note 6, at $\S 3(2)$. This requirement can also be satisfied by studying at a foreign university in a country designated by the Minister of Justice and which a South African university has certified awards a degree of equal or higher standard to one available from a South African university. §3(2)(a)(ii).

24. Id. at § $3(1)$.

25. General Council of the Bar of South Africa, South African LegalSystem,http://www.sabar.co.za/legal-system.html(last visited Jan. 6, 2010).

26. The regional bar associations are also known as Societies of Advocates and are located in major cities that house the high courts. See Peggy Maisel, An Alternative Model to United States Bar Examinations: The South African Community Service Experience in Licensing Attorneys, 20 GA. ST. U. L. REv. 977, 978 (2004).

27. See General Council of the Bar of South Africa Uniform Rules of Professional Conduct, available at http://www.sabar .co.za/ethics_rules.pdf.

28. In 1999, there were approximately 140 independent advocates. Independent advocates are not recognized as legitimate by the profession and can be generally divided into two categories: "those who were members of constituent Bars, but had left disgruntled about what they regard as the Bars' apparent conservatism and their continued reliance on archaic ethical rules" and those "who attempted to enter the advocates' profession, but could not pass the National Bar Examination. The disturbing aspect about this [last] group is that the majority of them are blacks." Seth A. Nthai, Advocate's Ethics: A Need for Reform?, 12 Consultus 2, at 27 (June 1999), available at http://www.sabar.co.za/law-journals/ list-of-journals.html. Additionally, some choose to become independent advocates because they cannot afford to spend one year in pupilage without a means of support. See, e.g., J. Joel Baloyi, Why I Intend Joining the Independent Bar, DE Rebus, Letters, Jan./Feb. 2007.

29. As mentioned above, advocates are not permitted to solicit clients directly, a limitation that is usually enforced on them by the disciplinary process of the GCB and the regional bars. Nonetheless, upon referral by the GCB the courts have disciplined independent advocates who violate this rule, and such rulings have been upheld by the Supreme Court of Appeals and the Constitutional Court.

30. Admission of Advocates Act 74 of 1964, supra note 6, at $\S 7(1)$. An advocate may be suspended or removed from the bar upon a finding that he or she is not a fit and proper person to practice, or for failure to maintain citizenship or residency requirements. An advocate may also be subject to fines and criminal prosecution for sharing fees with persons other than other advocates.

31. These bar associations are separate from those regulating attorneys, which are called Law Societies and are discussed in the section on the licensing of attorneys.

32. KwaZulu-Natal Bar, Pupillage, http://www.kznbar.co.za/ pupillage.asp (last visited Jan. 8, 2010).

33. The General Council of the Bar encourages pupils to be admitted prior to passing the National Bar Examination so that they will be eligible to practice immediately after passing the examination. However, this can create a situation in which a pupil fails the examination but is already admitted as an advocate. Some in this situation choose to practice as independent advocates without passing the examination, becoming members of what is termed the "rebel bar." The majority of advocates who take this route to practice are reported to be black. See Warren Radloff, Pupillage, 12 Consultus 3, at 2-4 (Sept. 1999); Nthai, supra note 28.

34. Chris Marnewick SC, Improving Our Pupillage System Stepby-Step, 19 Advocate 3, at 42-46 (Dec. 2006), available at http://www.sabar.co.za/law-journals/list-of-journals.html.

35. Lectures cover Legal Writing, Motion Court Practice and Procedure, Ethics, Criminal Procedure and Evidence, and Preparation for and Conduct of Civil Trials in both the High Court and Magistrate's Court. KwaZulu-Natal Bar, Pupillage, supra note 32.

36. Id.

37. The Johannesburg Bar, Pupillage at the Johannesburg Bar, http://www.johannesburgbar.co.za/pupillage.html (last visited Apr. 10, 2010).

38. Marnewick, supra note 34.

39. Archie Findley SC, National Bar Examination Board, 14 Advocate 2, at 36-37 (Aug. 2001), available at http://www .sabar.co.za/law-journals/2001/august/2001-august-vol014 -no2-pp36-37.pdf.

40. Marnewick, supra note 34.

41. National Bar Examination Board, 16 Advocate 1, at 7 (April 2003), available at http://www.sabar.co.za/law-journals/list -of-journals.html.

42. A.J. Dickson, One-Year Pupillage: A Review, 19 Advocate 3:35, at 35 (Dec. 2006), available at http://www.sabar.co.za/law -journals/list-of-journals.html.

43. Marnewick, supra note 34. 
44. This increased from a $64 \%$ pass rate in 2005 and $85 \%$ in 2006 , and was a result of the following changes implemented in the pupilage system between 2004 and 2006: (1) the increase in the period of pupilage from six months to one year, (2) the creation of a pupilage manual in workbook format through which pupils learn by doing, (3) providing for a supplementary examination in Legal Writing at the end of the year for those who failed, and (4) increasing the time between the written and oral portions of the exam to provide time for remedial teaching. Dickson supra note 42 , at 35-42.

45. Glenn Goosen SC, Pupillage Programme Continues to Flourish, 21 Advocate 3, at 16-19 (Dec. 2008), available at http://www .sabar.co.za/law-journals/list-of-journals.html.

46. See e.g. Marnewick, supra note 34.

47. Marnewick, supra note 34.

48. Id.

49. Dickson, supra note 42.

50. Marnewick, supra note 34.

51. Dickson, supra note 42.

52. The two contributors are Chris Marnewick, who at the request of the GCB developed the practical training workbook that has been successfully used since 2004, and A.J. Dickson, the first National Pupilage Coordinator.

53. Marnewick, supra note 34.

54. Id.

55. Dickson, supra note 42; Marnewick, supra note 34, at 45.

56. Dickson, supra note 42.

57. Id.

58. Maisel, supra note 26.

59. Meadows, supra note 21, at 475.

60. University of Cape Town, Faculty of Law, Practising Law in South Africa, http://www.law.uct.ac.za/generic.php? m=/ general/practice.php (last visited Jan. 7, 2010).

61. Maisel, supra note 26. However, an attorney does not automatically have the right to appear before the High Court. The right to practice before the High Court is acquired by applying in writing to the Court and submitting proof that the attorney has obtained an LL.B. or equivalent legal qualifications, and certification by the law society of which the attorney is a member that he or she has been practicing for three years and is in good standing. Right of Appearance in Courts Act 62 of $1995 \S$ 4, available at http://www.info.gov .za/view/DownloadFileAction?id=70982.

62. Attorneys Act, supra note 6, at $\S \S 4(\mathrm{c})$, (d); Maisel, supra note 26, at 979 (2004)

63. Attorneys Act, supra note 6, § 15, as amended in 1995. To prove that he or she is fit and proper to be admitted, an applicant must provide the court with two certificates of character, in affidavit form, by persons who have known the candidate for at least two years. These persons must be deposed by a person of good standing, preferably an advocate or attorney, who is not related to the applicant or affiliated with the firm or legal clinic where the applicant fulfilled the apprenticeship requirement. KwaZuluNatal Law Society, Admission of Attorneys in Terms of Section 15, available at http://www.lawsoc.co.za/default .asp?id=1586 (last visited Jan. 10, 2010). The act is currently being revised, so these requirements may change. See Legal Practice Bill, First Working Draft, 2009, supra note 12.

64. Prior to December 31, 2004, a B.Proc. was also sufficient.

65. Community service is defined as full-time service related to the application of the law at a legal clinic or at an office of the Legal Aid Board. Attorneys Act, supra note 6, at $\S 1$.

66. Those who have completed the four-month practical training course that qualifies candidates for a reduction of time in serving articles are not required to complete this course. Id. at $\S 15(1)(b)(i v A)$.

67. See id. at $\S \S 25-55$; Attorneys Fidelity Fund, http://www .fidfund.co.za/pages/fund_cert_text.htm (last visited Jan. 7, 2010). The Fund is a statutory body funded by the interest on practitioners' trust accounts the objective of which is to protect the public against loss as a result of the theft of trust funds.

68. The Law Society of South Africa, supra note 11.

69. Id. The four regional law societies are the Law Society of the Northern Provinces, the Cape Law Society, the KwaZulu Law Society, and the Free State Law Society.

70. Attorneys Act, supra note 6, at § 71(1).

71. Id. at $\S 72(1)$.

72. Maisel, supra note 26.

73. Attorneys Act, supra note 6, at $\S 2(1 \mathrm{~A}), 2 \mathrm{~A}$.

74. Id. at $\S 1$.

75. L.E.A.D. School for Legal Practice, available at http://www .lssalead.org.za/Uploads/files/LEAD\%20SCHOOLS\%20 BROCHURE\%20low\%20res.pdf. There are currently 10 legal practice schools in South Africa, all established after 1994, that teach this course. These schools are modeled after similar schools in Commonwealth countries such as England, Scotland, and Australia. They are often attached to universities although they are separately funded through the law societies and student tuition. A recent innovation has been to make distance learning available to those candidates who cannot attend a school in person. University of South Africa Annual Report 2006, at 84, available at http://www .unisa.ac.za/happening/docsWEBANNUALREPORT_2006 .pdf.

76. Attorneys Act, supra note 6, at §15(1)(b)(iv).

77. The modules train candidates in professional conduct; constitutional practice; court procedures, including special application to motor vehicle accidents; insolvency and matrimonial matters; drafting of contracts, wills, estates, 
and trusts; commercial litigation; and attorney practice management, including attorney's bookkeeping. In addition, modules cover aspects of gender law, advocacy, research, drafting, numeracy, and computers. Elective subjects are also provided in conveyancing, labor dispute resolution, forms of business enterprise, and aspects of customary law. Numeracy testing is conducted and, if a candidate is deemed deficient, separate numeracy training is compulsory. L.E.A.D. School for Legal Practice, supra note 75.

78. Thuli Mhlungu, Educating and Licensing Attorneys in South Africa, 20 GA. Sт. U. L. Rev. 1005 (2004).

79. Attorneys Act, supra note 6, at $\S 15(1)(\mathrm{b})(\mathrm{iv})$.

80. Module I, which prepares candidates for Paper 1 of the Attorneys' Admission Examination, covers constitutional practice, high court practice, magistrate's court practice, criminal court practice, motor vehicle accident claims, and aspects of gender law. Module II, which prepares candidates for Papers 3 and 4 of the examination, covers wills and estates, drafting of contracts, matrimonial law, and electives. Module II also covers legal practice skills such as professional conduct, introduction to practice management, legal costs, attorney's bookkeeping, value-added tax, and numeracy skills. As with the practical training course, numeracy skills are assessed, and compulsory training is required for those who fail the assessment.

Full-time courses are not offered over a continuous five-week training session but instead are scheduled so that students can complete Module I in time for the August examination and Module II in time for the February examination. Although attendance of the entire course is necessary to obtain the required certificate of attendance, candidates may choose to enroll for certain subjects only, and the cumulative number of courses attended is considered when issuing a certificate. Part-time courses are scheduled over approximately four months and prepare candidates to take the entire examination in August. L.E.A.D. Courses for Candidate Attorneys, available at http://www.lssalead.org .za/Uploads/files/A4\%20COURSES\%20BRO\%202010\%20 (ENG)_Final.pdf.

81. In 2008, the law firm Routledge Modise launched an inhouse legal training school that was accredited to fulfill the statutory requirement. However, learning outcome assessment and practice manuals were provided by L.E.A.D. Firm Launches New School for Candidate Attorneys, De Rebus, Oct. 2008, available at http://www.derebus.org.za.

82. See Law Society of South Africa Annual Report, April 2008 to March 2009, p. 36, available at http://www.lssa.org .za/Uploads/files/LSSA\%20ANNUAL\%20REPORT\%20 April\%2008\%20to\%20March\%2009.pdf.

83. In practice, this is a five-month training course.

84. Attorneys Act, supra note 6 , at $\S 14$.
85. The Attorneys' Admission Examination, Attorneys Admission Syllabus (2009), available at http://www.lawsoc.co.za/upload/ files/syllabus_2009_admission.pdf.

86. Id.

87. Attorneys Act, supra note 6, at $\S \S 4(\mathrm{a}),(\mathrm{b}),(\mathrm{c})$; Attorneys Admission Syllabus (2009), supra note 85.

88. Id.

89. Law Society AGM's: Calls for Proper Training of Candidate Attorneys, De Rebus, Feature Articles, Jan./Feb. 2009, available at http://www.derebus.org.za.

90. L.E.A.D. to Roll Out Massive Skills Development Training with R18 Million Sasseta Grant, De Rebus, LSSA News and Views, Nov. 2009, available at http://www.derebus.org.za.

91. See notes 73-74, supra, and accompanying text.

92. N. Malepa, Having to Serve Articles Is Unconstitutional, DE Rebus, Letters, Nov. 2001, available at http://www.derebus .org.za.

93. Emil Boshoff, Reply by Chairperson of the Law Society of South Africa's Standing Committee, De Rebus, Letters, Nov. 2001, available at http://www.derebus.org.za. These include taking a practical training course and fulfilling community service. See discussion, supra notes 73-74 and accompanying text.

94. As permitted by the Attorneys Act $\S 8(1)(a)$; Simhiwe Mtshengu, Law Society Should Monitor Training, De Rebus, Letters, March 2002, available at http://www.derebus.org.za.

95. Mtshengu, supra note 94.

96. Mtshengu, supra note 94; Tshepang Monare, Law Society Should Monitor Candidates' Training, De Rebus, Letters, Nov. 2001, available at http://www.derebus.org.za.

97. Boshoff, supra note 93.

98. Mhlungu, supra note 78, at 1010.

99. See notes 77-80, supra, and accompanying text for a description of the course.

100. Mhlungu, supra note 78 , at 1010-11.

101. Nic Stewart, Is the School for Legal Practice Relevant?, De Rebus, Letters, December 1999, available at http://www.derebus .org.za.

102. Chipa Nong, Is the Exam Still Relevant?, De Rebus, Letters, Sept. 1999, available at http://www.derebus.org.za.

103. The Law Society of England and Wales, How to Practice in South Africa, http://international.lawsociety.org.uk/ip/ africa/566/practice (last visited Jan. 7, 2010).

104. Prospective Candidate Attorneys and Admission as Attorneys: Foreign Qualifications, available at http://www.chr.up .ac.za/academic_pro/1lm2/opps/Prospective\%20candidate \%20attorneys.pdf.

105. As described earlier, the process is obtaining an LL.B. from a South African university, completing articles of clerkship or one of the alternatives, passing the Attorneys' Admission Examination, and usually completing a legal training course. See notes 63-66 and 68-71, supra, and accompanying text. 
106. The Law Society of SouthAfrica, Qualification of Foreignersas Attorneys in South Africa, available at http://www.lssa.org.za/ Uploads/files/QUALIFICATION\%20OF\%20FOREIGNERS .pdf.

107. Attorneys Act, supra note 6, at $\S 2(\mathrm{cA})$.

108. Id. at $\S 2(\mathrm{aB})$.

109. The Law Society of South Africa, Qualification of Foreigners as Attorneys in South Africa, supra note 106.

110. Attorneys Act, supra note 6, at §13; The Law Society of South Africa, Qualification of Foreigners as Attorneys in South Africa, supra note 106.

111. Attorneys Act, supra note 6, at § 17; The Law Society of South Africa, Qualification of Foreigners as Attorneys in South Africa, supra note 106.

112. Murray Hawkins, Questions and Answers: Australian Legal Education and Bar Admissions, 77 The Bar Examiner 1:11, at 11 (Feb. 2008).
113. Regulations as to Intrants, 8-9 (Faculty of Advocates Ed. 2006), available at http://www.advocates.org.uk/downloads/ becoming_training/regintrants_2009.pdf.

114. The Law Society of Scotland, Diploma in Legal Practice, http://www.lawscot.org.uk/training/Diploma.aspx (last visited Mar. 3, 2010); Two Year Vocational Training, http:// www.lawscot.org.uk/training/Training.aspx (last visited Mar. 3, 2010).

115. See The Law Society, Junior Lawyers, Qualification Stages, http://juniorlawyers.lawsociety.org.uk/career/solicitors (last visited Mar. 3, 2010).

116. See Bar Standards Board, Vocational Stage, http://www.bar standardsboard.org.uk/Educationandtraining/aboutthebvc (last visited Mar. 3, 2010).

117. See Lonbay, supra note 2. 